\title{
Menginisiasi Perilaku Positif Masyarakat Tentang Penyakit ISPA di Desa Muntoi Timur Kabupaten Bolaang Mongondow
}

\author{
Hamzah Burhan ${ }^{1}$ \\ ${ }^{1}$ Program Studi S1 Kesehatan Masyarakat \\ STIKES Graha Medika Kotamobagu, Jalan Siswa, Kelurahan Mogolaing Kotamobagu 95716 \\ Email korespondensi: hamzahbskm@gmail.com
}

\begin{abstract}
Abstrak
Infeksi saluran pernapasan akut adalah penyakit saluran pernapasan atas atau bawah, yang dapat menimbulkan berbagai spektrum penyakit yang berkisar dari penyakit tanpa gejala atau infeksi ringan sampai penyakit yang mematikan. Tingginya kasus infeksi saluran pernapasan akut di Desa Muntoi Timur disebabkan oleh masuknya musim kemarau yang mengakibatkan banyaknya debu dan cuaca panas serta masih kurangnya pengetahuan masyarakat tentang infeksi saluran pernapasan akut. Tujuan pengabdian ini adalah untuk meningkatkan pengetahuan masyarakat Desa Muntoi Timur Kecamatan Passi Barat Kabupaten Bolaang Mongondow tentang infeksi saluran pernapasan akut. Kegiatan pengabdian ini dilaksanakan di Desa Muntoi Timur Kecamatan Passi Barat dengan sasaran warga dusun 04 dan 05. Metode yang digunakan adalah ceramah interaktif dan tanya jawab. Hasil kegiatan ini adalah sebelum penyuluhan rata-rata skor pengetahuan peserta tentang ISPA adalah 9,86, dan setelah penyuluhan skor pengetahuan meningkat menjadi 15,57 . Disarankan perlu adanya peran aktif tenaga kesehatan untuk selalu memberikan pendidikan kesehatan kepada masyarakat terkait penyakit infeksi saluran pernapasan akut, supaya masyarakat dapat meningkatkan derajat kesehatannya secara mandiri.
\end{abstract}

Keywords: Infeksi saluran pernapasan akut, pengetahuan, penyuluhan

\begin{abstract}
Acute respiratory tract infections are diseases of the upper or lower respiratory tract, which can cause a wide spectrum of diseases ranging from asymptomatic or mild infections to deadly diseases. The high cases of acute respiratory infections in East Muntoi Village are caused by the arrival of the dry season which causes a lot of dust and hot weather and the lack of public knowledge about acute respiratory infections. The purpose of this service is to increase the knowledge of the people of East Muntoi Village, Passi Barat District, Bolaang Mongondow Regency, about acute respiratory infections. This service was carried out in Muntoi Timur Village, Passi Barat District with the target of hamlets 04 and 05. The method used was interactive lecture and question and answer. The results of this activity were before counseling the average knowledge score of participants about acute respiratory infections was 9.86, and after counseling the knowledge score increased to 15.57. It is recommended that an active role of health workers be needed to always provide health education to the community related to acute respiratory infections, so that the community can improve their health independently.
\end{abstract}

Keywords: Acute respiratory infections, knowledge, counseling 


\section{PENDAHULUAN}

Infeksi saluran pernapasan akut (ISPA) adalah penyakit saluran pernapasan atas atau bawah, yang dapat menimbulkan berbagai spektrum penyakit yang berkisar dari penyakit tanpa gejala atau infeksi ringan sampai penyakit yang parah dan mematikan. ISPA berlangsung sampai 14 hari yang dapat ditularkan melalui air ludah, darah, bersin maupun udara pernafasan yang mengandung kuman (Wijayaningsih, 2013). Namun demikian, sering juga ISPA didefinisikan sebagai saluran pernapasan akut yang disebabkan oleh agen infeksius yang ditularkan dari manusia ke manusia. Timbulnya gejala biasanya cepat, yaitu dalam waktu beberapa jam sampai beberapa hari. Gejalanya meliputi demam, batuk dan sering nyeri tenggorok, pilek, sesak napas, mengik, atau kesulitan bernapas (Masriadi, 2017).

Oktami R.S (2017) dalam (Ervi Imaniyah, 2019) mengemukakan bahwa infeksi saluran pernapasan akut atau sering disebut sebagai ISPA adalah terjadinya infeksi yang parah pada bagian sinus, tenggorokan, saluran udara, atau paru-paru. Infeksi yang terjadi lebih sering disebabkan oleh virus meski bakteri juga bisa menyebabkan kondisi ini. Berdasarkan data WHO dalam (Putra \& Wulandari, 2019) bahwa \pm 13 juta anak balita di dunia meninggal setiap tahun dan sebagian besar kematian tersebut terdapat di Negara berkembang di Asia dan Afrika seperti: India (48\%), Indonesia (38\%), Ethiopia (4,4\%), Pakistan (4,3\%), China (3,5\%), Sudan (1,5\%), dan Nepal (0,3\%). Dimana ISPA merupakan salah satu penyebab utama kematian dengan membunuh \pm 4 juta dari 13 juta anak balita setiap tahun.

Berdasarkan data Riskesdas tahun 2018 prevalensi ISPA di Indonesia berdasarkan diagnosis tenaga kesehatan sebesar $4,4 \%$ dan berdasarkan diagnosis tenaga kesehatan dan gejala sebesar 9,3\% (Kemenkes RI, 2018). Meskipun secara nasional prevelensi ISPA dari tahun 2013-2018 cenderung mengalami penurunan, namun kondisi ini masih mengkhawatirkan dimana ISPA masih menjadi masalah kesehatan masyarakat karena dibeberapa daerah angka penemuan kasus ISPA masih masuk dalam lima besar angka penyakit tertinggi misalnya di daerah Kabupaten Bolaang Mongondow Sulawesi Utara.

Penyakit ISPA di Kabupaten Bolaang Mongondow masih cukup tinggi, dimana pada periode Januari-Juni 2019 penemuan penyakit ISPA berada pada posisi ketiga di Bolmong sebanyak 533 kasus (Dinkes Bolaang Mongondow, 2019). 
Berdasarkan data studi pendahuluan di dusun 04 dan 05 Desa Muntoi Timur diperoleh kasus ISPA terbanyak dengan 121 kasus, disusul hipertensi sebanyak 66 kasus dan alergi sebanyak 42 kasus. Kondisi ini ditambah dengan masuknya musim kemarau yang mengakibatkan banyaknya debu dan cuaca panas serta masih kurangnya pengetahuan masyarakat tentang ISPA. Hasil Studi pendahuluan pada 10 warga dusun 04 dan 05 Desa Muntoi Timur menunjukkan bahwa hanya 60\% yang tahu tentang pengertian ISPA, 30\% yang tahu tentang penyebab ISPA, $40 \%$ yang tahu tantang faktor risiko, gejala dan tanda ISPA, dan hanya 50\% yang tahu pencegahan dan tatalaksana ISPA.

Hasil penelitian sebelumnya menunjukkan bahwa tingginya angka kasus ISPA dipengaruhi oleh rendahnya pengetahuan masyarakat tentang penyakit ISPA. Hal ini dibuktikan oleh penelitian yang dilakukan di Desa Purworejo Kecamatan Padangan Kabupaten Bojonegoro dengan jumlah sampel sebanyak 193 responden, menemukan bahwa ada hubungan pengetahuan tentang polusi udara dengan terjadinya ISPA pada masyarakat yang bermukim di dekat jalan raya di Desa Purworejo Kecamatan Padangan Kabupaten Bojonegoro dengan nilai $p=0,000$ (Azizah, 2011). Penelitian lain yang dilakukan di Desa Dawungsari dengan jumlah sampel sebanyak 72 responden, menemukan bahwa ada hubungan yang signifikan antara pengetahuan orang tua tentang ISPA dengan kejadian ISPA pada balita di Desa Dawungsari Kecamatan Pegandon Kabupaten Kendal dengan nilai p value 0,031<0,05 (Indah Wulangningsih, Witri Hastuti, 2018).

Berdasarkan latar belakang yang telah diuraikan maka tujuan kegiatan pengabdian masyarakat ini adalah meningkatkan perilaku positif dalam hal ini pengetahuan tentang ISPA pada masyarakat Dusun 04 dan 05 di Desa Muntoi Timur Kecamatan Passi Barat Kabupaten Bolaang Mongondow melalui pendidikan kesehatan.

\section{MASALAH}

Permasalahan yang dihadapi Mitra dalam pencegahan dan penanganan penyakit ISPA adalah masyarakat masih kurang informasi tentang pengertian, penyebab, faktor risiko, gejala dan tanda, pencegahan dan tatalaksana/terapi ISPA. 


\section{METODE}

Pengabdian masyarakat ini dilaksanakan di Desa Muntoi Timur. Sasaran pelaksanaan kegiatan adalah seluruh warga dusun 04 dan 05 Desa Muntoi Timur Kecamatan Passi Barat Kabupaten Bolaang Mongondow. Kegiatan yang dilakukan meliputi tiga tahap yaitu tahap perencanaan, tahap pelaksanaan, dan tahap evaluasi. Tahap perencanaan dimulai dengan mencari informasi mengenai ISPA melalui jurnal, artikel penelitian atau pengabdian masyarakat serupa.

Kegiatan pengabdian diawali dengan memberikan kuesioner tentang ISPA dengan tujuan untuk evaluasi pengetahuan awal peserta penyuluhan tentang ISPA. Selanjutnya dilakukan penyuluhan kesehatan tentang ISPA yang terdiri dari pengertian, penyebab, faktor risiko, gejala dan tanda, pencegahan dan tatalaksana/terapi ISPA. Penyuluhan ini dilakukan dengan metode ceramah interaktif, tanya jawab berhadiah dan pembagian leaflet.

Evaluasi dilakukan dengan memberikan kuesioner yang sama seperti awal kegiatan dengan tujuan untuk evaluasi pengetahuan peserta penyuluhan setelah pengabdian.

Adapun rincian kegiatan yang dilakukan sebagai berikut :

1) Pre test

Pada tahap ini dilakukan pengukuran pengetahuan masyarakat tentang ISPA yang meliputi pengertian, penyebab, faktor risiko, gejala dan tanda, pencegahan dan tatalaksana/terapi ISPA. Pengukuran menggunakan kuesioner dengan 20 item pernyataan (Elisti, 2015). Jika jawaban responden benar maka di beri skor 1 sebaliknya jika jawaban salah diberi skor 0 .

2) Tahap pelaksanaan

Pada tahap ini dilakukan penyampaian materi tentang pengertian, penyebab, faktor risiko, gejala dan tanda, pencegahan dan tatalaksana/terapi ISPA. Metode penyuluhan menggunakan ceramah interaktif, kemudian untuk meningkatkan partisipasi masyarakat dilakukan diskusi berhadiah. Yang kemudian dilanjutkan dengan pemberian leaflet tentang ISPA. 


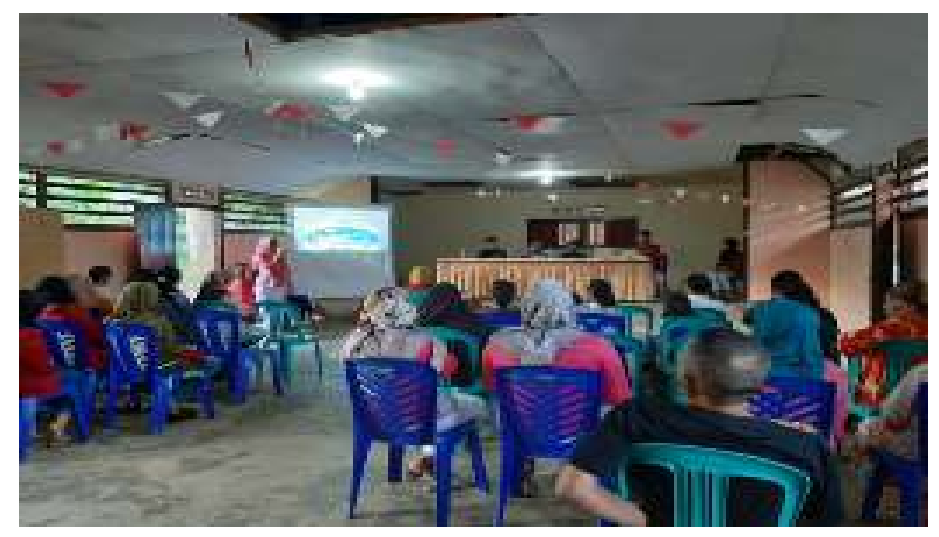

Gambar 1. Penyampaian materi ISPA

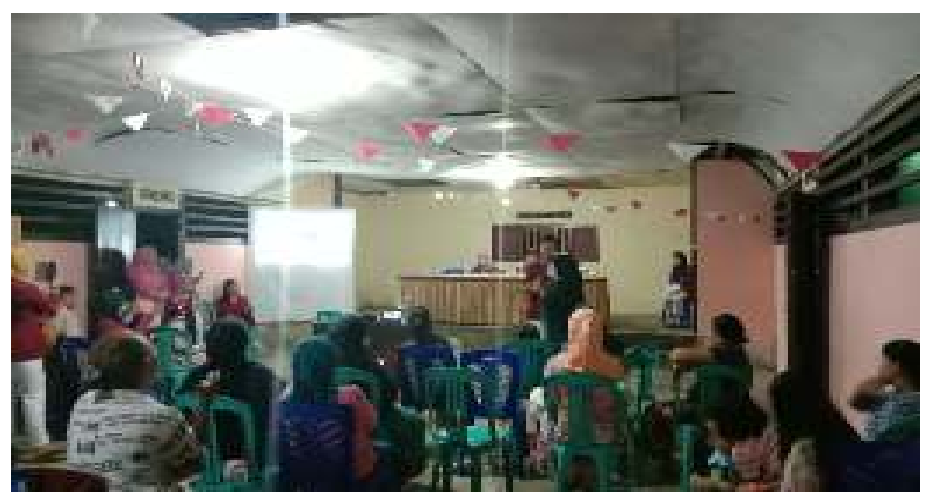

Gambar 2. Proses Diskusi Peserta

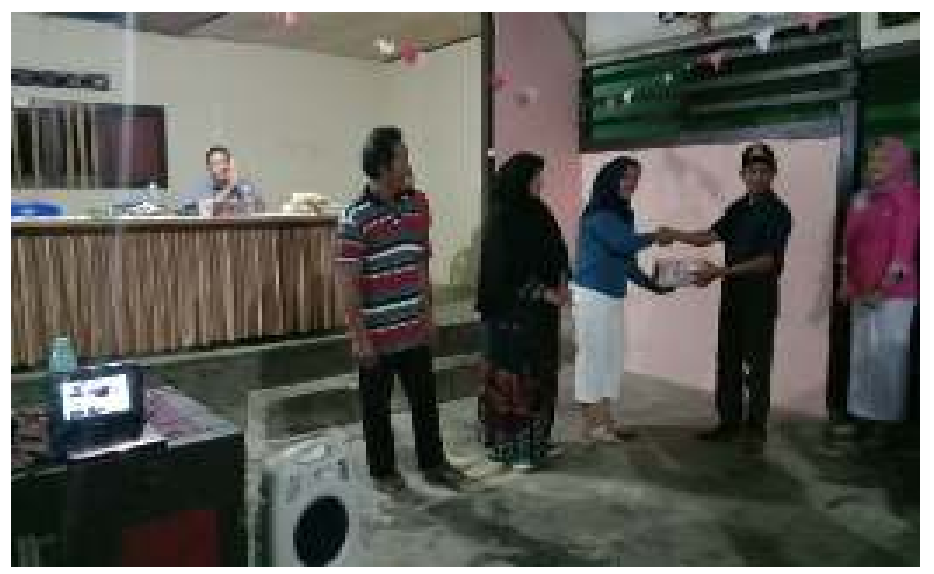

Gambar 3. Pemberian Hadiah

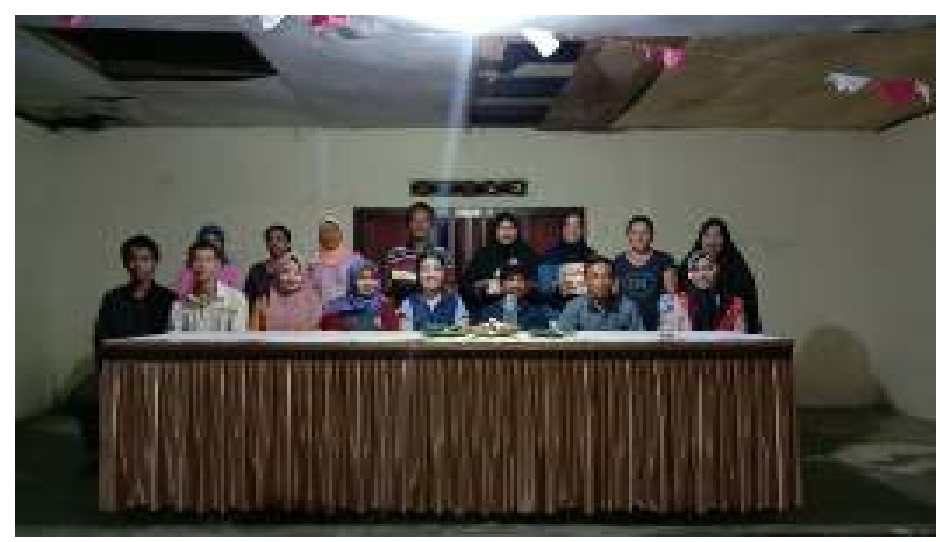

Gambar 4. Foto Bersama 
3) Post test

Pada tahap ini dilakukan pengukuran tingkat pengetahuan masyarakat tentang ISPA setelah dilakukan penyuluhan kesehatan. Pertanyaan kuesioner meliputi pengertian, penyebab, faktor risiko, gejala dan tanda, pencegahan dan tatalaksana/terapi ISPA.

\section{HASIL DAN PEMBAHASAN}

1) Hasil

Hasil kegiatan pengabdian pada warga Dusun 04 dan 05 Desa Muntoi Timur Kecamatan Passi Barat Kabupaten Bolaang Mongondow sebagai berikut:

Tabel 1. Karakteristik umum peserta penyuluhan Dusun 04 dan 05 Desa Muntoi Timur Kecamatan Passi Barat Kabupaten Bolaang Mongondow (N:35)

\begin{tabular}{clcc}
\hline No. & $\begin{array}{l}\text { Karakteristik Peserta } \\
\text { Penyuluhan }\end{array}$ & frekuensi & \% \\
\hline 1. & Jenis Kelamin & 16 & 45,7 \\
& Laki-laki & 19 & 54,3 \\
2. & Kerempuan & & \\
Kelompok Umur (Tahun) & 3 & 8,6 \\
20-25 & 5 & 14,3 \\
26-31 & 20 & 51,4 \\
32-37 & 9 & 25,7 \\
38-42 & & \\
Pendidikan Terakhir & 2 & 5,7 \\
Tidak tamat SD & 1 & 2,9 \\
Tamat SD & 20 & 57,1 \\
Tamat SMP & 5 & 14,3 \\
Tamat SMA & 7 & 20,0 \\
Sarjana & & \\
Pekerjaan & 16 & 45,7 \\
IRT & 9 & 25,7 \\
Petani/Buruh & 7 & 20 \\
Pedagang/Wiraswasta & 3 & 8,6 \\
PNS/TNI/Polri & $\mathbf{3 5}$ & $\mathbf{1 0 0}$ \\
\hline
\end{tabular}

Tabel 1 menunjukkan bahwa peserta penyuluhan yang berjenis kelamin perempuan sebanyak 54,3\% dan yang berjenis kelamin laki-laki sebanyak 45,7\%. Kelompok umur peserta penyuluhan paling banyak yaitu 32-37 tahun sebesar $51,4 \%$ dan paling sedikit kelompok umur 20-25 tahun sebesar 8,6\%. Karakteristik pendidikan peserta penyuluhan paling banyak adalah tamat SMP sebesar 57,1\% dan yang paling sedikit adalah tamat SD sebesar 2,9\%, sedangkan untuk karakteristik pekerjaan peserta penyuluhan paling banyak adalah Ibu Rumah Tangga (IRT) sebesar 45,7\% dan paling sedikit adalah PNS/Pegawai sebesar 8,6\%. 
Tabel 2. Perbandingan prosentase jawaban sebelum dan sesudah kegiatan penyuluhan tentang ISPA pada warga Dusun 04 dan 05 di Desa Muntoi Timur Kecamatan Passi Barat Kabupaten Bolaang Mongondow

\begin{tabular}{|c|c|c|c|c|c|}
\hline \multirow{3}{*}{ No. } & \multirow{3}{*}{ Pernyataan } & \multicolumn{4}{|c|}{ Peserta Penyuluhan } \\
\hline & & \multicolumn{2}{|c|}{ Pre test } & \multicolumn{2}{|c|}{ Post test } \\
\hline & & n & $\%$ & n & $\%$ \\
\hline 1. & ISPA hanya menyerang saluran pernapasan atas & 26 & 74,3 & 29 & 82,9 \\
\hline 2. & ISPA hanya menyerang bagian hidung & 9 & 25,7 & 24 & 68,6 \\
\hline 3. & ISPA hanya disebabkan oleh bakteri & 5 & 14,3 & 27 & 77,1 \\
\hline 4 & $\begin{array}{l}\text { ISPA penyakit berbahaya karena dapat mengakibatkan } \\
\text { kematian pada balita }\end{array}$ & 27 & 77,1 & 34 & 97,1 \\
\hline 5 & Kurang gizi merupakan faktor risiko ISPA & 23 & 65,7 & 27 & 77,1 \\
\hline 6 & $\begin{array}{l}\text { Resiko kematian karena ISPA lebih banyak terjadi pada } \\
\text { orang dewasa dari pada balita }\end{array}$ & 5 & 14,3 & 23 & 65,7 \\
\hline 7 & $\begin{array}{l}\text { Menjaga gizi dan menghindari alergen merupakan cara } \\
\text { mencegah terkena ISPA }\end{array}$ & 20 & 57,1 & 25 & 71,4 \\
\hline 8 & $\begin{array}{l}\text { Gangguan saluran pernapasan atas lebih berbahaya/berat } \\
\text { daripada gangguan saluran napas bawah }\end{array}$ & 20 & 57,1 & 28 & 80 \\
\hline 9 & Jika demam, sudah pasti terkena penyakit ISPA & 20 & 57,1 & 31 & 88,6 \\
\hline 10 & $\begin{array}{l}\text { Kejang-kejang pada balita tidak berbahaya, biasa terjadi } \\
\text { jika suhu badan terlalu tinggi }\end{array}$ & 7 & 20 & 26 & 74,3 \\
\hline 11 & $\begin{array}{l}\text { Anak usia 2-12 bulan, memiliki napas cepat jika lebih } \\
\text { dari 50x/menit }\end{array}$ & 29 & 82,9 & 33 & 94,3 \\
\hline 12 & $\begin{array}{l}\text { Jika balita tidak bisa minum/menghisap ASI harus dirujuk } \\
\text { ke dokter }\end{array}$ & 27 & 77,1 & 31 & 88,6 \\
\hline 13 & Jika demam dikompres dengan air hangat & 29 & 82,9 & 34 & 97,1 \\
\hline 14 & $\begin{array}{l}\text { Memberi banyak cairan dapat mengurangi demam, batuk } \\
\text { dan pilek }\end{array}$ & 17 & 48,6 & 24 & 68,6 \\
\hline 15 & Parasetamol adalah obat untuk menurunkan demam & 32 & 91,4 & 34 & 97,1 \\
\hline 16 & $\begin{array}{l}\text { Jika mengalami asma/mengi yang berulang harus diberi } \\
\text { obat pelega napas }\end{array}$ & 9 & 25,7 & 21 & 60 \\
\hline 17 & $\begin{array}{l}\text { Dosis parasetamol untuk balita sama dengan orang } \\
\text { dewasa yaitu } 500 \mathrm{mg}\end{array}$ & 10 & 28,6 & 20 & 57,1 \\
\hline 18 & $\begin{array}{l}\text { Anak umur kurang dari } 3 \text { bulan dapat diberi parasetamol } \\
\text { tanpa anjuran dokter }\end{array}$ & 13 & 37,1 & 23 & 65,7 \\
\hline 19 & Antibiotik harus diminum rutin sampai habis & 18 & 51,4 & 27 & 77,1 \\
\hline 20 & Salbutamol contoh obat untuk mengatasi asma/mengi & 15 & 42,9 & 23 & 65,7 \\
\hline
\end{tabular}

Tabel 2 menunjukkan 20 item pernyataan pengetahuan peserta penyuluhan tentang ISPA. Pernyataan pengetahuan yang mengalami peningkatan jawaban benar yaitu pernyataan "ISPA hanya disebabkan oleh bakteri" dimana pada saat pre test hanya 5 orang (14,3\%) yang menjawab dengan benar dan mengalami peningkatan yang cukup signifikan pada saat post test yaitu menjadi 27 orang $(77,1 \%)$ yang menjawab dengan benar. Sedangkan pernyataan pengetahuan yang mengalami peningkatan dengan jumlah peningkatan yang relatif kecil yaitu pernyataan "Parasetamol adalah obat untuk menurunkan demam" dimana pada saat pre test telah banyak yang menjawab dengan benar yaitu 32 orang $(91,4 \%)$ dan meningkat menjadi 34 orang $(97,1 \%)$ pada saat post test. 
Tabel 3. Perbandingan skor rata-rata pengetahuan sebelum dan sesudah penyuluhan tentang ISPA pada warga Dusun 04 dan 05 di Desa Muntoi Timur Kabupaten Bolaang Mongondow

\begin{tabular}{lcc}
\hline & \multirow{2}{*}{ Nilai Statistik } & \multicolumn{2}{c}{ Skor Pengetahuan } \\
\cline { 2 - 3 } & Pre test & Post test \\
\hline Minimum & 6 & 10 \\
Maksimum & 15 & 19 \\
Mean & 9,86 & 15,57 \\
SD & 2,130 & 2,146 \\
\hline
\end{tabular}

Tabel 3 menunjukkan bahwa rata-rata skor pengetahuan peserta penyuluhan tentang ISPA pada saat pre test adalah 9,86 dengan standar deviasi 2,130, dan pada saat post test meningkat menjadi 15,57 dengan standar deviasi 2,146. Skor pengetahuan terendah pada saat pre test adalah 5 dan skor tertinggi adalah 32 dan pada saat post test skor pengetahuan terendah pada adalah 21 dan skor tertinggi adalah 34. Berdasarkan hasil analisis terdapat perbedaan nilai rata-rata skor pengetahuan peserta penyuluhan pada saat pre test dan post test dengan angka 5,71. Hal ini menunjukkan bahwa ada peningkatan pengetahuan peserta penyuluhan setelah diberikan pendidikan kesehatan terkait dengan pengertian, penyebab, faktor risiko, gejala dan tanda, pencegahan dan tatalaksana/terapi ISPA.

Peningkatan pengetahuan masyarakat ini disebabkan karena penerimaan masyarakat terhadap materi yang diberikan sangat baik. 20 pernyataan yang diberikan rata-rata skor pengetahuan mengalami peningkatan yang cukup signifikan. Pengetahuan yang baik akan mendorong masyarakat untuk berperilaku positif tentang penyakit ISPA. Perilaku positif masyarakat tentang ISPA dapat timbul karena adanya kesesuaian reaksi atau respon terhadap stimulus tertentu yaitu pengetahuan mengenai penyakit ISPA. Teori menjelaskan bahwa perilaku seseorang ditentukan oleh faktor yaitu faktor predisposisi, faktor pendorong, dan faktor penguat. Pengetahuan merupakan salah satu faktor predisposisi yang mendasari perilaku seseorang untuk berperilaku positif. Pengetahuan yang baik tentang penyakit ISPA dapat mempengaruhi masyarakat dalam meningkatkan kewaspadaan dini terhadap penyakit ISPA (Notoatmodjo, 2014).

Beberapa faktor pendukung dan penghampat pada kegiatan pengabdian masyarakat ini adalah faktor pendukung yaitu adanya kesadaran masyarakat untuk memelihara kesehatan dengan perilaku positif melalui penerapan PHBS dirumah tangga, antusiasme dan partsipasi aktif dari para peserta yang cukup besar dalam mengikuti kegiatan penyuluhan kesehatan ini. Faktor penghambat yaitu kebiasaan 
masyarakat yang tidak ada waktu untuk memelihara kesehatan secara mandiri, dan jika ingin ke pelayanan masyarakat terdekat memerlukan biaya yang besar, dan peran kader kesehatan yang masih bersifat pasif, sehingga masyarakat belum menyeluruh memperoleh informasi tentang ISPA.

\section{KESIMPULAN}

Kegiatan pengabdian masyarakat ini berjalan dengan baik. Terlihat dari penerimaan baik oleh pihak Desa Muntoi Timur dan antusias masyarakat dusun 04 dan 05 untuk mengikuti kegiatan penyuluhan. Serta tercapainya target yang diharapkan dengan meningkatnya pengetahuan masyarakat tentang ISPA, dimana rata-rata skor pengetahuan masyarakat sebelum penyuluhan adalah 9,86 dan setelah penyuluhan skor meningkat menjadi 15,57.

Disarankan perlu adanya peran aktif kader kesehatan untuk selalu memberikan pendidikan kesehatan kepada masyarakat khususnya di Desa Muntoi Timur terkait penyakit ISPA. Supaya masyarakat dapat meningkatkan derajat kesehatannya secara mandiri.

\section{DAFTAR PUSTAKA}

Azizah, F. E. A. S. (2011). Hubungan Pengetahuan Tentang Polusi Udara Dengan Terjadinya Ispa Pada Masyarakat. Asuhan Kesehatan: Jurnal Penelitian Kesehatan, 2(2).

Dinkes Bolaang Mongondow. (2019). Profil Kesehatan Kabupaten Bolaang Mongondow Tahun 2019.

Elisti, A. (2015). Evaluasi Pengetahuan Ibu-Ibu PKK tentang Penyakit ISPA Sebelum dan Sesudah diberi Edukasi dengan Ceramah dan Leaflet di Kabupaten Grobogan. Universitas Muhammadiyah Surakarta.

Ervi Imaniyah, I. J. (2019). Determinan Kejadian Infeksi Saluran Pernapasan Akut (ISPA) pada Balita. Jurnal Ilmiah Kebidanan Indonesia, 9(01).

Indah Wulangningsih, Witri Hastuti, A. I. P. (2018). Hubungan Pengetahuan orang Tua tentang ISPA dengan Kejadian ISPA pada Balita di Desa Dawungsari Kecamatan Pegandon Kabupaten Kendal. Jurnal SMART Keperawatan, 5(1), 90-101.

Kemenkes RI. (2018). Hasil Utama Riset Kesehatan Dasar (Riskesdas). 
Masriadi. (2017). . Epidemiologi Penyakit Menular. Raja Grafindo Persada.

Notoatmodjo, S. (2014). Ilmu Perilaku Kesehatan. Rineka Cipta.

Putra, Y., \& Wulandari, S. S. (2019). Faktor Penyebab Kejadian Ispa. Jurnal Kesehatan, 10(1), 37. https://doi.org/10.35730/jk.v10i1.378

Wijayaningsih. (2013). Asuhan Keperawatan Anak. CV. Trans Info Media. 